\title{
The Influence of International Trade on Chinese Technology Innovation Capacity of Hi-Tech Industry

\author{
Pei HU
}

\begin{abstract}
School of Economy, Zhongnan University of Laws and Economics, City of Wuhan, Province of Hubei, China, 430000.
\end{abstract}

Keywords: International trade, Technology innovation capacity, Hi-Tech industry.

\begin{abstract}
The paper used panel data from 1996-2012 of Hi-Tech industry to analyze the influence of export and import, $R \& D$ expenditure and research personnel on the Chinese enterprises' technology innovation capacity. The empirical result states that international trade has positive effect on technology innovation capacity, in which the influence of import is stronger than that of the export. In addition, international trade has relatively more significant impact in eastern district than in middle and western district.

Innovation is, in general, the new production method, new products and new organization of the industry in economic world. Innovation assist to decrease unit production cost and extend the market for enterprises which can enhance its competitiveness. Endogenous innovation and exogenous innovation are usual classification, in order to pursue larger profit based on the defeat of their competitors; companies are willing to initiate the innovation procedure to obtain monopoly in the market. The desire of success leads those companies to invest in innovation, especially in the circumstance of thorough protection system of patent and intellectual property, which is called endogenous innovation.

Exogenous innovation refers to the research output from high-education colleges and non-profit institutions, those innovations can be transferred to new products and new process technology. The importance of innovation to companies, to specific extent, to the high-tech companies, is turning the unique products and the substantial financial profit into reality. The companies' capacity of translating products innovation and technology imitation from others to its own productivity is crucial factor as to whether or not it can achieve the financial values, and we call this capacity as technology innovation capacity.
\end{abstract}

\section{Reviews of the Relevant Literatures}

\section{Technology Innovation Capacity}

Tidd. \& Bessant. (2009) proposed that technology innovation is defined as the complicated process to transfer the innovation into production, including searching phase for product value, filtering phase and realization phase. The evaluation of the influences of technology innovation on company's performance is composed of the entire three phases. Technology innovation capacity is the bridge linking various kinds of producing resources and expected production. Song et al.(2007) thought that the enterprises lack of technology innovation capacity are unable to create or guarantee the competitive advantages in the market, even they possess abundance of productions resources. Therefore, it's the technology innovation capacity that maximizes the innovation output.

Technology innovation capacity is determined by financial value created by market. Application of new invention is taken as technology innovation as long as the 
innovation effect has been expanded to the whole market and brings about the financial profit for companies who need innovation. Garcia \& Calantone (2002) divided technology innovation into two common categories: basic technology innovation and additional innovation. The former means the application of new technology in production procedure; while the later indicates the performance enhancement on the existing products.

Technology innovation capacity is related to the internal environment such as level of companies' technology development, companies' scale, as well as the external environment. By absorbing and imitating the innovation from competitors and R\&D institutions, companies are entitled the opportunity of develop its own technology innovation capacity. That's to say, the technology spillover effect from learning-by-doing is one of the most important way to gain new technology. Cohen \& Levinthal (1998) took the technology innovation as the process of learning from external environment and application of new technology. Technology innovation capacity improvement, to some extent, is strengthening the capacity of learning and absorbing the new technology to reinforce companies' core competitiveness.

\section{Technology Spillover Effect of International Trade}

Higher-quality requirement of customers abroad for products necessitate the domestic export company's desire to improve its technology to broaden international market for entry permission. Export, as one channel for those companies getting into foreign advanced technology, can develop domestic technology and enhance the according technology innovation and productivity.

Technology can be also transferred internationally through import, the technology spillover effect of import is achieved by domestic import company's production of similar products at lower cost based on imitation. The import of more skilled intermediate products can generate and increase the technology accumulation for hosting countries which improves the productivity and innovation capacity for domestic companies.

Comprehensive empirical papers have analyzed the relationship between trade and domestic productivity and technology development. Coe and helpman (1995) are worthy of being mentioned when we investigate the close relationship of trade and technology spillover. They found that a country will benefit more from import from countries with higher technology level than from countries with lower technology. Keller (1997a, 2000) put some doubt on this finding and his empirical results show that whether or not trade influences a country's technology is decided by the import structure. If a country import from various countries with different skill intensity, the technology diffusion is not strongly related with trade, which reveals the fact that import composition is vital in the technology spillover effect. Xu and Wang (1999) confirmed this hypothesis in his paper. Sjoholm (1996) uses citations of patents as measure to calculate the influence of trade on multinational technology flow and discovered the positive coefficient between these two variables. This support the opinion that imports contributes to international technology spillover. Eaton and Kortum (2001) established a framework to estimate international trade's knowledge spillover for 34 countries with different level of economy and found this effect is embodied in the import destinations and not so clear.

As for export, a great number of studies, including Rhee, Pursell (1984), Bernard and Jensen (1996) as well as Tybout (2000) have verified that companies can learn through export. But this kind technology spillover is not strongly confirmed by more papers. 
From the above research, we can see a strong link in technology innovation and enterprises' performance. International trade, acting as an approach of technology spillover, is indispensible to manufacture new products and to improve core competitiveness for enterprises. This paper attempts to confirm this relationship for Chinese enterprises in Hi-Tech industry, after all, the related research is rare.

\section{International Trade and Hi-Tech Industry in China}

As indicated in figure 1, the technology innovation capacity of Hi-tech industry in China (measured by the new products of the year) has developed at a steady and fast pace since the end of the 90s. Notwithstanding the growth downturn in 2008, it still shows the strong rebound in 2009 and remains the increase tendency of the growth rate of $17.5 \%$ approximately per year except some peak and low-development years. It's noticeable that the changes of import and export show the amazingly accordance with that of the amount of the new products. The year 2004 deserves focus for the reason of the dividing line since this year. Before 2004, these three variables demonstrate incredibly the same rate of growth. Afterward, the new products began to develop more rapidly than import and export, exceeding both of them in the year 2009 . It's also the time the technology innovation output performed a steep and prompt increase trend. As discussed above, import and export, two factors contribute to the evolution of technology innovation capacity, showed almost the synchronized change in the meantime except a sharp downturn during the period of 2008-2009.

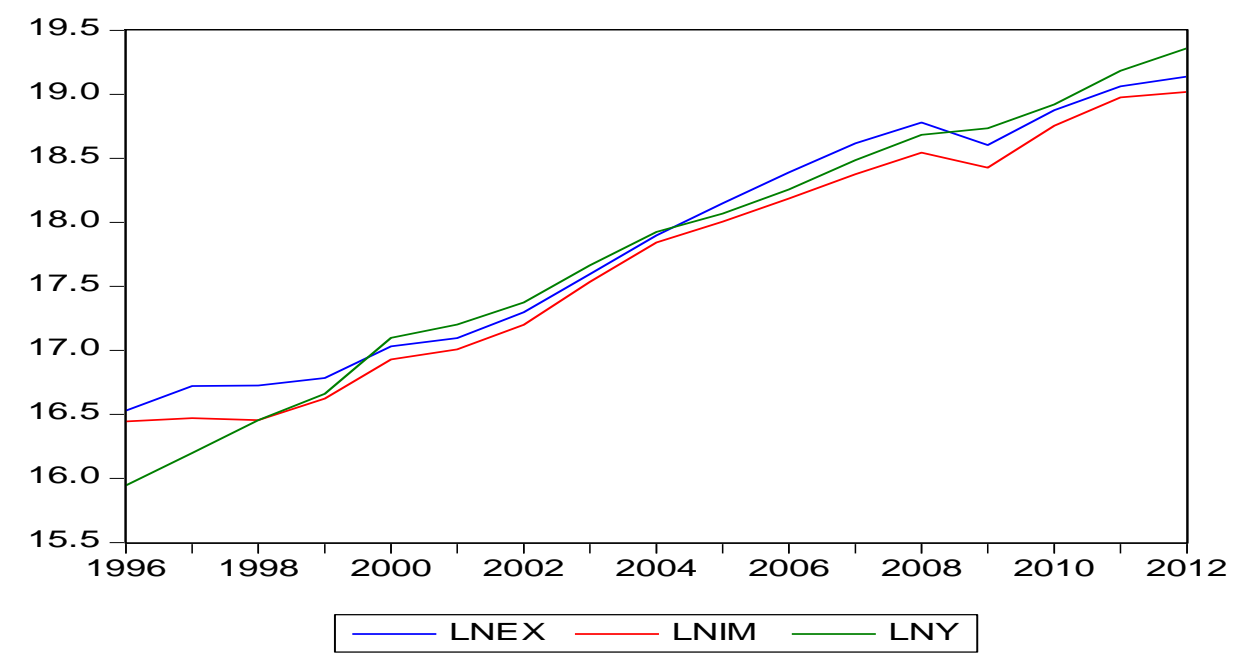

Figure 1: the growth rates of export and import in China. Note: Data are calculated by indexing the series at $1996=100$ and by transforming the annual value into natural logarithm.

Apart from international trade, an understanding of China's technology growth performance in Hi-tech industry essentially based on some internal factors, such as technology staff, R\&D expenditure etc. Trade indeed acts vital role by allowing for skill- intensive commodities globally to enhance one country's technology progress. We still have to proximately analyze elements underlying China's technology change in Hi-tech industry in the long run by undertaking a number of variables including the above ones mentioned.

The requirement of stainable growth of technology makes it necessary of human capital and a large sum of $R \& D$ expenditure. The quantity of research staff and $R \& D$ signified great increase over the last decade which is shown in figure 2. It's evident that the amount of both variables expresses the similar changing path. However, the 
R\&D expenditure increases more quickly than research staff which continues the steady upward trend before 2004. One point needs to be mentioned is that R\&D keep increasing even during the period of 2008-2009, while there has been a sharp decrease in the growth rate of research staff.

China has begun the economic reform since 1978, this overall policies transfer may be the reason for this striking similarity of those five variables. The increase of research staff is guaranteed by the enrollment expansion of higher education policy to provide more population of high skill and knowledge. At the same time, the policies like the openness of trade and encouragement of self-reliable innovation generate the rise in the amount of trade and $R \& D$ input. All the rising human capital, $R \& D$ expenditure and trade establish a consolidate base for domestic capacity for introducing and absorbing technology in order to develop its own technology innovation capacity in the long haul. These facts build a case for international trade in terms of external factor, as well as for research staff and R\&D in terms of internal factors to determine long-run growth of Chinese technology improvement.

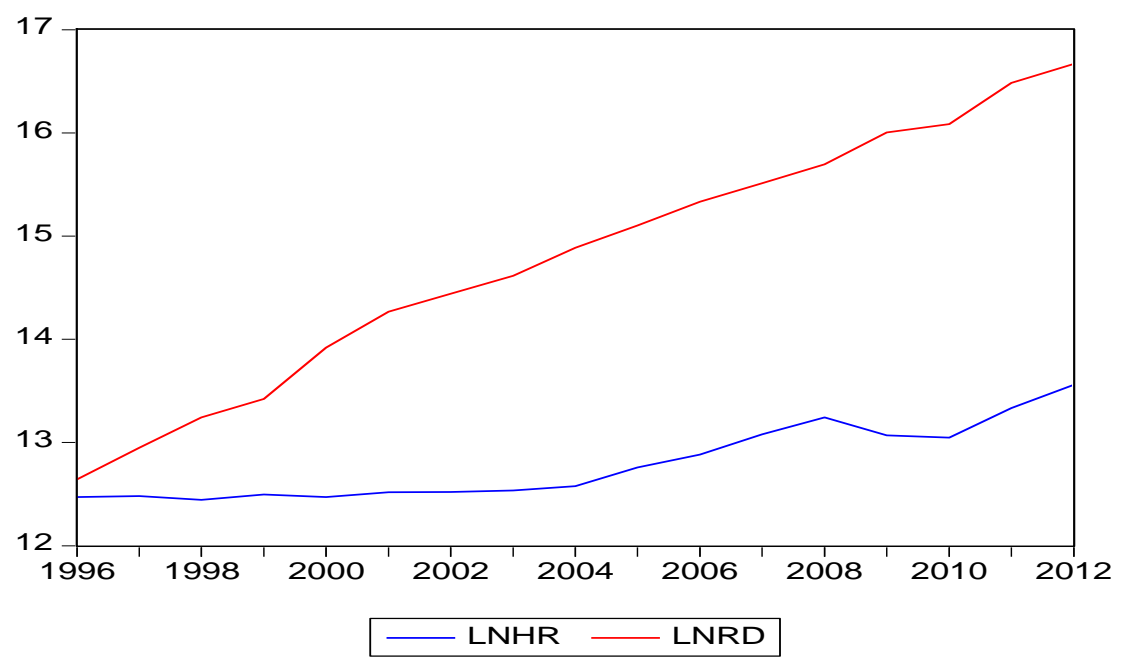

Figure 2: the growth rates of $R \& D$ and research staff in China. Note: Data of $R \& D$ is calculated by indexing the series at $1996=100$ and by transforming the annual value into natural logarithm.

\section{Model and Data}

The production function in the paper follows Arrow's (1962) model.

$$
Y_{i t}=A_{i t} K_{i t} \text {. }
$$

$Y_{i t}$ means the quality of new products in Hi-tech industry of province $\mathrm{i}$ for year $\mathrm{t}$, which is used to measure the companies' technology innovation capacity. The following $i$ and $t$ are of the same implication, Quality of new products and patents are the normal evaluation of technology innovation capacity, considering that it's not possible for all the patents to be transferred into material production successfully, we take quality of new products to measure the level of technology innovation capacity when taking into account the actual capacity.

$A_{i t}$ indicates technology level impacted mainly by $\mathrm{R} \& \mathrm{D}$ staff $H R_{i t}$ and international trade of Hi-Tech products $H T_{i t}$. The internal R\&D expenditure is taken for the index of technology innovation capital input by $K_{i t}$. Except for the district of 
Hannan, Chongqing and Xizang, subscript of $\mathrm{i}$ includes all areas of China.

Data in this paper are taken from the Statistical Yearbook of Chinese Hi-Tech industry, Chinese Technology Statistical Yearbook and Chinese Statistics Yearbook from 1997 to 2013. All variables are dealt with GDP deflator, we choose the year 1996 as the base year. By taking R\&D staff HR and Hi-tech international trade HT into Formula (1), it can be transferred into the following log function:

$$
\ln Y_{i t}=\ln H T_{i t}+\ln H R_{i t}+\ln R \& D_{i t} .
$$

In addition, we adjust model (2) into the formula (3) by dividing variable international trade into export and import specifically.

$$
\ln Y_{i t}=\alpha_{0}+\alpha_{1} \ln I M T_{i t}+\alpha_{2} \ln E X T_{i t}+\alpha_{3} \ln H R_{i t}+\alpha_{4} \ln R \& D_{i t}+u_{0} .
$$

In which, IMT and EXT express the amount of export and import of China respectively. The paper adopts OLS method, in order to get the robust results and avoid spurious regression, unit-root test is necessary and we found that original series are not stationary, while table 1 shows the test results of the first difference series which demonstrates the stationary characteristics, so we take the $\operatorname{AR}(1)$ variables to do the empirical analysis.

Table 1 unit-root test of variables

\begin{tabular}{cccc}
\hline \hline Variables & ADF & PP & PSW \\
\hline \hline$\Delta \ln \mathrm{Y}$ & $333.995 * * *$ & $426.957 * * *$ & $-18.3191 * * *$ \\
$\Delta \operatorname{lnIMT}$ & $196.906 * * *$ & $279.425 * * *$ & $-12.5899 * * *$ \\
$\Delta \operatorname{lnEXT}$ & $203.043 * * *$ & $235.553 * * *$ & $-13.0282 * * *$ \\
$\Delta \operatorname{lnHR}$ & $289.827 * * *$ & $398.197 * * *$ & $-15.0642 * * *$ \\
$\Delta \operatorname{lnRD}$ & $313.407 * * *$ & $388.982 * * *$ & $-16.3242 * * *$ \\
\hline \hline means p-value $\leq 0.01, * *$ means p-value & $\leq 0.05, *$ means p-value $\leq 0.1$
\end{tabular}

Table 2 enables us to see the relationship between the above independent variables and dependent variable. The first column represents the effect of export on Chinese companies' technology innovation capacity. The second column indicates the effect of import. The third column, when considered the compound effect, doesn't change the results obviously. It's noticeable that significant positive correlation exists between international trade and companies' technology innovation capacity in Chinese Hi-tech industry, in the meantime, the amount of research staff and R\&D expenditure assist in promoting innovation capacity for those Hi-tech companies. They play the equivalent role to raise Chinese technology level with coefficient as $40 \%$ and $42 \%$ approximately. Even coefficients of export and import are less than that of the other two explanatory variables; they still reach to the level of $24 \%$ and $23 \%$ respectively.

The main factors of improving Chinese technology innovation capacity in Hi-tech industry are human capital and R\&D expenditure. Technology innovation capacity is base on the technology innovation which can only realized by connecting with research and development and production activity to form an innovative production chain of certain economic scale. And the whole process can't be successful if lack of a very crucial factor, labor. It acts as the bridge to link all the above elements together. The technology staff can customize innovative technology and apply them in the product design and production ability. That makes the quality of research staff the limit of companies' technology innovation capacity. It's important to absorb international advanced technology and improve domestic technology after optimizing the structure of research personnel, reinforcing their ability of research and 
autonomous innovation.

Table 2 OLS fixed effect regress results

\begin{tabular}{cccc}
\hline \hline & 1 & 2 & 3 \\
\hline \hline $\operatorname{lnIMT}$ & & $0.404720^{* * * *}$ & $0.248227 * *$ \\
& & $(5.761961)$ & $(2.414245)$ \\
$\operatorname{lnEXT}$ & $0.429330^{* * *}$ & & $0.231847 * *$ \\
& $(5.619897)$ & & $(2.077014)$ \\
$\ln \mathrm{HR}$ & $0.335777 * * *$ & $0.451543 * * *$ & $0.401085^{* * *}$ \\
& $(4.653218)$ & $(6.184341)$ & $(5.231016)$ \\
$\operatorname{lnRD}$ & $0.482566 * * *$ & $0.445451 * * *$ & $0.427402^{* * *}$ \\
& $(10.07237)$ & $(8.514231)$ & $(8.090087)$ \\
$\mathrm{C}$ & -0.957751 & -1.644828 & -2.231474 \\
& $(-1.524453)$ & $(-1.292116)$ & $(-1.551575)$ \\
sample & 446 & 446 & 446 \\
$\mathrm{R}^{2}$ & 0.9286 & 0.9289 & 0.93 \\
\hline \hline
\end{tabular}

Furthermore, Hi-tech industry is characterized of intense capital and technology, innovation capacity is directly related to the capital expenditure. Higher technology level of the whole industry can't be reached without the large amount investment in $\mathrm{R} \& \mathrm{D}$. compared to the developed countries, the ratio of $\mathrm{R} \& \mathrm{D}$ expenditure/industrial output is rather low, with $1.68 \%$ in 2012. The same index in America and Britain reached to as high as more than $10 \%$. That's the reason we need to increase the R\&D expenditure in Hi-tech industry and inspire companies to turn to multiple financing methods, it's the way to solve the financing difficulty for innovative enterprises especially for SMEs.

From the results of table 2, it demonstrates the expected positive relationship between international trade and technology innovation capacity, coefficient of import is 0.248 which is almost the identical as that of export, but still little higher. The reason behind is that developed countries are probably main import destinations involved in the hi-tech industry's trade; those countries have remarkably technology spillover effect for domestic production. The increase in the amount of international trade is beneficial for technology diffusion and translation. To be specific, domestic companies introduced the technology abroad and translate into its own production ability through outsourcing and intermediate trade, in the other way, domestic exporters are forced to innovate in order to meet the rigorous entry standard and formalities set by foreign countries. These two active and passive innovation incentives will definitely improve the technology innovation capacity for home country.

In fact, economic differences among various areas in China are obvious and inevitable. The following part is to analyze the regional variation as to the technology innovation capacity. We classify the whole country into three parts in accordance with Chinese regionalism. That's, the eastern, the middle and the western. We get the empirical result in table 3 .

We can see from table 3 that import and regional technology innovation capacity are positively related, with the highest coefficient of 0.217 for the eastern in China, which means that innovation capacity will increase $0.62 \%$ on the basis of $1 \%$ increase in the amount of import. The influence in the western is the least and slightest of 0.082. The coefficients of export for the middle and the western are not significant, only significant for the eastern. The western in China has constant geographic and 
economic advantages compared to the other two regions. It has played as the pioneer and center in economic development for the whole country since the national reform in 1978. Take the year 2011as an example, the amount of new products, the R\&D expenditure and profit in the eastern are roughly several times more than that of the middle and the western. Not only the innovative input and out, but also the innovative capacity outperformed the other two districts.

Table 3 regress results for region-level in China

\begin{tabular}{|c|c|c|c|}
\hline & The eastern & The middle & The western \\
\hline \multirow[t]{2}{*}{$\operatorname{lnIMT}$} & $0.217012 * *$ & $0.121299 * * *$ & $0.082640 *$ \\
\hline & $(1.409756)$ & $(4.678130)$ & (0.398558) \\
\hline \multirow[t]{2}{*}{$\operatorname{lnEXT}$} & $0.209729 *$ & -0.160670 & 0.552544 \\
\hline & $(3.488263)$ & $(-0.982955)$ & $(2.408402)$ \\
\hline \multirow[t]{2}{*}{$\operatorname{lnHR}$} & $0.196633^{* *} *$ & 0.525735 *** & 0.562354 *** \\
\hline & $(2.127352)$ & $(3.014516)$ & $(3.951381)$ \\
\hline \multirow[t]{2}{*}{$\ln R D$} & $0.784327 * * *$ & $0.322130 * * *$ & $0.383087 * * *$ \\
\hline & (11.08891) & (3.410119) & $(4.150906)$ \\
\hline \multirow[t]{2}{*}{$\mathrm{C}$} & 4.527114 & -4.123647 & -4.868859 \\
\hline & (4.389900) & $(-2.281001)$ & $(-2.214261)$ \\
\hline sample & 160 & 128 & 158 \\
\hline $\mathrm{R}^{2}$ & 0.938 & 0.825 & 0.882 \\
\hline
\end{tabular}

*** means p-value $\leq 0.01, * *$ means p-value $\leq 0.05, *$ means p-value $\leq_{0.1}$

It deserves emphasizing that the technology spillover effect of import is stronger than export; the reason is probably that the industries of electronic and communication, the computer and office devices are the most marketable business of the largest amount of export in Hi-tech manufacturing. Primary consecutive imitation and following endeavor of autonomous innovation have made these two businesses into the competitive manufacturers in international market to some extent. While we can't deny the core technical gap between those companies and the giants in other countries, especially when we sacrifice the low-cost labor, natural resources and rely on the enticement for the foreign direct investment so as to get so-called completive advantages. It's the cause we claim for the limited effect of export on the technology innovation capacity.

\section{Conclusions and Suggestions}

Hi-tech industry is a skill-intensive and capital intensive business, the most decisive factor that make the company survive in the market for the long haul is its technology innovation capacity. From the above analysis, the innovative input such as R\&D expenditure, research staff etc. is positively related with this kind of capacity. The increase in the amount of these elements can improve the production capacity of new products. What's more, international trade inspires enterprises' incentive to innovate. For the purpose of sustainable development and long-term innovation capacity improvement in China, we propose the following suggestions:

The cornerstone of Hi-tech industry is innovation which is a complicated procedure combining the capital and advanced ideas into the mixed result, namely, innovation. This combination requires sufficient fund to support the research, to transfer this kind of thought into reality. The fact is that large fraction of $R \& D$ funds for Chinese enterprises in this industry come from the local government. Few alternatives of financing methods limit companies' opportunity to pursue innovative commodities 
and production. The urgency to improve the productivity necessitates the multiple financing floor, investment in the creative Hi-tech enterprises and venture investment customized for China. Meanwhile, perfection in law of intellectual property is the other way to unload the financial burden for companies already troubled by the innovative cost.

Moreover, we have to attach importance on the technology spillover effect of international trade. Outsourcing and intermediate trade liquidate the technology in the form of products from country to country. Since the transfer of international technology centre from Europe to the America, accompanied with the fact of international economic centre transfer in the same direction. International trade, to be precise, the import, is helpful to the introduction of new product, new process and new technology to develop domestic technology.

We can't ignore the regional differences of technical development and should take action to support the weak ones and make this disparity vanish gradually. Up to the year 2013, $107 \mathrm{Hi}$-tech industry zones have been established in China (except three areas of Chongqing, Hannan, Xizang) with the distribution of 54 in the eastern, 32 and 21 in the middle and the eastern. The unbalance can be taken advantage if keeping the eastern as the radiant point of technology diffusion to the other districts, then to the whole industry and economy. Of course, the excessive inequality generates a great number of social problems, so it's indispensible to increase the innovative input, to development the international trade in the middle and the western in the long haul.

\section{Reference:}

[1] Tidd, J., Bessant, J., 2009. Managing innovation; integrating technological, market and organizational change, 4 th ed.

[2] Garcia, Calantone(2002)A critical look at technological innovation typology and innovativeness terminology: a literature review Original Research Article Journal of Product Innovation Management, Volume 19, Issue 2, March 2002, Pages 110-132

[3] Cohen, W.M., Levin, R.C., 1989. Empirical studies on innovation and market structure In: Schmalensee, R., Willig, R.D. (Eds.), Handbook of Industrial Organization. North-Holland, New York, pp. 1059-1107.

[4] Coe, D.T., and E. Helpman (1995), "International R\&D Spillovers", EuropeanEconomic Review 39: 859-887.

[5] Keller, W. (2000), "Do trade patterns and technology flows affect productivity growth? ", World Bank Economic Review 14: 17-47.

[6] Keller, W. (1997a), "Technology flows between industries: Identification and productivity effects", Economic Systems Research 9: 213-220.

[7] Xu, B., and J. Wang (1999), "Capital Goods, Trade and R\&D Spillovers in the OECD", Canadian Journal of Economics 32: 1258-1274.

[8] Sjöholm, F. (1996), "International transfer of knowledge: the role of international trade and geographic proximity", Weltwirtschaftliches Archive 132: 97-115.

[9] Eaton, J., and S. Kortum (2001b), "Technology, geography, and trade", mimeo, Boston University, May. 
[10]Tybout, J. (2000), "Manufacturing firms in developing countries: How well do they do, and why? ", Journal of Economic Literature 38 (March): 11-44.

[11]Amiti Koning (2012)Trade Liberalization and the Wage Skill Premium: Evidence from Indonesia Original Research Article Journal of International Economics, Volume 87, Issue 2, July 2012, Pages 277-287.

[12] Arrow, Kenneth, "Economic welfare and the allocation of resources for invention," in "The rate and direction of inventive activity: Economic and social factors," Princeton: Princeton University Press, 1962, pp. 609-626.

[13] Hale Utar (2013) international competition and industrial evolution:Evidence from the impact of Chinese competition on Mexican maquiladoras. Journal of Development Economics, Volume 105, November 2013, Page 267-287.

[14] John Wiley \& Sons Ltd., Chichester, England. Song, M., Benedetto, A.D., Nason, R.W., 2007. Capabilities and financial performance: the moderating effect of strategic type. Journal of the Academy of Marketing Science 35, 18-34.

[15] Oscar Alfranca (2009) Technical innovation in Spain's wood-based industry: The role of environmental and quality strategies. Forest Policy and Economics 11 (2009) $161-168$.

[16]Woondong Yeo (2015) A bibliometric method for measuring the degree of technological innovation. Technological Forecasting \& Social Change 95 (2015) $152-162$. 